\title{
Chapter 6. Dreams of The Fun Palace and Plug-In City - Architectural Modularism and Cybernetics in the 1960s
}

Dr Claire McAndrew, UCL Institute for Digital Innovation in the Built Environment The Bartlett, University College London

\section{Introduction}

This chapter considers the neo-futurist visions of two architectural designs from the 1960s, Archigram's Plug-In City ${ }^{1}$ designed by Peter Cook in 1964 and The Fun Palace ${ }^{2}$ conceived by Cedric Price in the same year. Each was radical in thinking around architectural modularism and in the case of The Fun Palace - the embrace of cybernetic thought. Their designs speculated on visions that were temporally adaptive and represented an idealistic belief in a better future, with an aspiration to drive flexibility and versatility from a collection of modular units that could be arranged and re-arranged, time and time again. Reversing the assumed stability of architectural form, The Fun Palace and Plug-In City were conceived as systems where human activity could control and modify the spatial form within which it was framed and so, ad infinitum. Blending modular architecture, technology and society, these two designs sought to provide liberation from modernism.

Reviewing material made accessible through The Archigram Archival Project hosted by the University of Westminster and the Cedric Price Collection held at the Canadian Centre for Architecture, this chapter examines some of the key expressions of neo-futurism captured by these 1960s designs. Through this commentary, it sheds light on the ways in which time has been conceived of being designed into the architectural fabric of cities, and how, through the examination of critical debates, we might find relevance for design history today and for the design of contemporary living in the digital age. 


\section{New possibilities for architecture}

Formed in 1960 at the Architecture Association in London, Archigram was formed of six architects and designers: Peter Cook, Warren Chalk, Ron Herron, Dennis Crompton, Michael Webb and David Greene. ${ }^{3}$ This avant-garde collective focused their attention on the new possibilities for architecture, creating fictional alternatives around the aesthetic and functionality of cities. Archigram produced nine (and a half!) issues of an experimental publication that featured these visions and went by the same name - Archi meaning architecture; and gram taking its meaning from the urgency associated with a telegram.

Plug-In City was designed by Peter Cook in 1964, but is considered the outcome of a number of ideas produced in the early years of the collective. These included for example, Cook's metal housing cabin (also known as Young People's Housing) designed in 1961 which employed a megastructure of concrete within which removable living capsules were inserted, aptly described as 'car body type units on precast guts'. ${ }^{4}$ It was also informed by The Nottingham Shopping Centre Project designed in 1962 with David Greene. Shared permanent shop and office buildings as well as expendable mobile shop units serviced via a tunnel system and removed by cranes, sought to resolve the problems of frequent servicing and unit replacement. ${ }^{5}$

The Living City exhibition at the Institute of Contemporary Arts in London which featured Peter Cook's Come-Go Project (also known as City With Existing Technology) in 1963 - a speculative proposal for an infrastructure of services, communications and facilities which would allow cities to literally 'come and go' - was also instrumental in the formulation of the Plug-In City concept. ${ }^{6}$ Issue 2 of Living Arts Magazine which served as the catalogue to the exhibition, sought to articulate this vitality in a manifesto and series of written/illustrated viewpoints. Here, Peter Cook expresses a restlessness with the permanence of built form against the ever-quickening pace of city life:

'Fashion' is a dirty word, so is the word 'Temporary', so is 'Flashy'. Yet it is the creation of those things that are necessarily fashionable, temporary or flashy that has 
more to do with the vitality of cities than 'monument-building'. The pulsation of city life is fast, so why not that of its environment? It reflects rise and fall, coming and going ... change, so why not build for this? ${ }^{7}$

Through the eyes of the collective, architecture was seen as just one part of the city. Vivid portrayals in the exhibition and accompanying catalogue, playfully referred to the other parts (man, survival, crowd, movement and communication) as 'gloop subjects'. Such gloops were conceived as compartments of the giant brain of the computer that contributed to the totality of the living city. Through such works, it became obvious that the studio ought to explore how the city as a whole, could be designed and programmed for change.

\section{Self-destroying, self-building}

The Plug-In City is arguably not really a city, but a constantly evolving and moving megastructure. Modular residential units 'plug-into' a central infrastructure which incorporates transportation, offices, leisure, even bad weather balloons which inflate to protect its inhabitants (Figure 1). Featured in Archigram Magazine Issue No.4 (1964), the aspiration was to drive flexibility and versatility from a collection of modular units that could be arranged and re-arranged, time and time again. Its aesthetic, imparts its radical timebased ethic: 'The dynamic processes of Plug-In - its ethic - had to be made visible, and so became an aesthetic. Plug-In City turned architecture inside-out to make its interior life anterior; expendable apartments were slung happily down the outside of the huge A-frame substructures, rearranged by the cranes sliding back and forth above. ${ }^{8} \mathrm{~A}$ hierarchy of relative permanence is exposed in what were labelled as 'sustenance components', with units planned for obsolescence. ${ }^{9}$ The main megastructure was suggested to last forty years, down to kitchens, living rooms and bathrooms changed every three years.

[Figure 1 here] 
In an article written by Priscilla Chapman that was published in the Sunday Times supplement magazine on 20 September 1964, she notes: 'On a technical level it is set apart from other plans by its purchase on life as it will be in the future. It grasps the rate at which people and things will change and, in effect, acknowledges throw-away architecture'. ${ }^{10}$ Cook's analogy of nourishing the city, is not lost on Chapman with her noting Archigram's basic message that 'the home, the whole city and the frozen pea pack are all the same'.11 Nor is the restructuring of the relation between people and built form. Describing Plug-In City as a 'self-destroying, self-building system' she notes the inversion of this relationship, that 'it is easily pushed into the shape people want it to be - rather than its pushing people into shape'. ${ }^{12}$

It was not just Archigram, who had an interest in architectural design and its plasticity. Eccentric and outlandish, this collective certainly pushed this ethic to its limit: 'Archigram injected flexibility with amphetamines and envisaged adaptability on a daily, if not hourly, basis. ${ }^{13}$ Looking back, Mike Webb reflects on how the adaptation of buildings to changes in user needs captured the spirit of the 1960s more generally - again, mirrored in Cedric Price's proposition for The Fun Palace.

\section{'Events in time, rather than objects in space'}

Reversing the assumed stability of architectural form, The Fun Palace was also conceived as a system of exchange where human activity could control and modify the spatial form within which it was framed. The Fun Palace was the brainchild of Joan Littlewood (theatrical producer), Cedric Price (architect), Gordon Pask (systems consultant) and Frank Neweby (structural engineer). The brief was to create a theatre like no other, a space that could transform to host plays, dance performances, wrestling, even political rallies. It was never the intention for it to become a multi-purpose venue, the aspiration was far more visionary: to drive flexibility and versatility from a collection of modular units that can be arranged and re-arranged, time and time again. Working with Frank Newby, Cedric Price developed the 
structural scaffold for the programme. Vertical towers would not only hold vital services, but would be crowned with cranes that hoist the modules into temporary formations.

The closing statement of the brochure for The Fun Palace (Figure 2) reads: 'We are building a short-term plaything in which all of us can realise the possibilities and delights that a $20^{\text {th }}$ century city environment owes us. It must last no longer than we need it. ${ }^{14}$ This disposability, parallels the throw-away ethic of Plug-In City. Imagined with process in mind, Stanely Matthews has even gone so far as to describe The Fun Palace as 'events in time rather than objects in space'. ${ }^{15} \mathrm{~A}$ statement that could equally be applied to the imaginings of Archigram.

[Figure 2 here]

What ultimately distinguished The Fun Palace from the Plug-In City, was its embrace of cybernetic thought. As Stanley Matthews describes, Gordon Pask set out the general aim of the Cybernetics committee - of which British Artist Roy Ascott whose work spans cybernetics and telematics was a part - as the development of 'new forms of environment capable of adapting to meet the possibly changeful needs of a human population and capable also of encouraging human participation in various activities. ${ }^{16}$ Electronic sensors and response terminals would be instrumental to the collection of information on leisure preferences. The computational power of an IBM 360-30 mainframe computer would provide the specification for spatial modification by detecting clusters of trends. Not simply responsive to human need, The Fun Palace would be anticipatory: understanding patterns of behaviour and forecasting future activities through cybernetic principles and game theory.

\section{Coming to grips with the near future}

By Archigram Magazine Issue No.4 - the very same issue that featured Plug-In City increasing reference was being made to Cedric Price's Fun Palace. The shortcomings of 1960s architectural practice, was becoming progressively more juxtaposed against their 
near future imaginaries of an architecture of speed and movement: 'One of the greatest weaknesses of our immediate urban architecture is the inability to contain the fast-moving object as part of the total aesthetic - but the comic imagery has always been strongest here. The representation of movement-objects and movement-containers is consistent with the rest, and not only because 'speed' is the main gesture. ${ }^{17}$ That discussions were underway at this time about the viability of locating The Fun Palace along the Lea Valley in East London did not go unmissed. ${ }^{18}$ Price was described as the only architect in England translating these ideas into reality and 'coming to grips with the near future'. ${ }^{19}$

Later in Archigram Magazine Issue No.7 entitled Beyond Architecture (December 1966), we see seventeen loose sheets and an electronic resistor in a plastic bag (Figure 3). Indicative as Dennis Crompton has since noted, of a time when electronics was moving into miniaturisation. ${ }^{20}$ In this issue, we see continued cross-referencing between Price and Cook.

First, the Time Essay written by Peter Cook with the sub-heading Get In There INTO 1967 You You You It's Up to You. It reads... 'By 1967 Archigram will have been outbursting for some six years. The Littlewood/Price Fun Palace will be three years old ... Already there is discussion of a second generation of programmed/expendable/clip-on etc. projects ... But where have we actually got? ${ }^{21}$ He provides comment on the failing of architecture to keep up with technological progress and an ultimatum to the Archigram readership. To continue with architecture as mere decoration or to embrace the future and collaborate with programmers, electronics engineers, bio-physicists and so on.

We see this call for change, reflected in a second feature, the cut-out which invites its readers to engage in tactile experimentation with the underlying ethos of Plug-In City and The Fun Palace - taking Littlewood's original idea of a 'kit of parts'. ${ }^{22}$

[Figure 3 here]

And third, in an article authored by Cedric Price, we see another call to action. This time directed at architects and planners: '.. it is essential that architects and planners start 
exercising their skills in producing proposals and artifacts whose nature, form, performance and expectancy of life will enable activities and actions hitherto unimaginable in both content and frequency. ${ }^{23}$ This is not to say this is a task of ease, it will be one that requires 'conscious design application in calculated uncertainty'. ${ }^{24}$ Like Cook, Price shared a dissatisfaction with the lack of change envisgaed with buildings and city form, with such assumptions implying human life to be static!

\section{Translating architectural dreams}

Purely fantasy during the 1960s, we now find ourselves in an era where people and 'things' are feeding data across the city, shaping our engagement in a dynamically recursive manner. The burgeoning Internet of things, rise of big data applications and step-changes in building information modeling connecting digital data with designed objects, will undoubtedly shift our temporal relationship with cities further still. The design history of the Plug-In City and The Fun Palace can offer direction in this future.

Most arresting about these 1960s designs is their fundamentally social ethos. In an interview with Cedric Price on 13 April 2000, Matthews recounts his declaration that 'The Fun Palace wasn't about technology. It was about people. ${ }^{25}$ The same can of course be argued for Archigram, with its desire to realign the pulsating city with a more flexible architectural form. And yet, there seemed to be an eventual suppression of social framing, and privileging of mathematically-informed cybernetic models in the case of The Fun Palace. ${ }^{26}$ Even the call for collaboration in Beyond Architecture focused on almost everyone but, the social scientists (featuring 'programmers' within this list captures this technological zeitgeist).

The works of French Philosopher Henri Bergson - although never directly referenced by Cedric Price - have been cited by Stanley Matthews as a useful lens through which to understand The Fun Palace. He suggests that for Bergson 'reality was not discrete objects and isolated matter but an endless and seamless process of becoming'. ${ }^{27}$ Looking toward contemporary social theory might furnish designs of the future with a temporal knowledge of 
why humans inhabit the world the way they do, how they form, change and develop over time or even disappear. Theodore Schatzki's philosophical account of the constitution and transformation of social life through a meshing of orders (e.g. people, artifacts, things) and practices (e.g. organised activities) over time, offers one such direction and brings the benefit of being firmly rooted in what he calls the 'site of the social'. ${ }^{28}$

This type of conversation is all the more urgent now as we start to see the rise of responsive environments, everyday objects imbued with sensors and 'things' that 'speak' to one another. The social applications (and implications) of which, remain in their infancy. They are typically defined as 'objects in space' and could arguably do much to borrow from Price's idea of 'events in time'. Put simply, we should not be thinking of the Internet of things as objects in space, but what they can enable as happenings over time.

The idea of a theory of conversation, seemed a natural development from Gordon Pask's work in cybernetics. Originating in the 1970s, it describes how human-to-human, human-to-machine and machine-to-machine interactions can lead to the construction of knowledge. The relevance to today, has not gone unnoticed:

Now, at the beginning of the 21st century, Pask's Conversation Theory seems particularly important because it suggests how, in the growing field of ubiquitous computing, humans, devices and their shared environments might coexist in a mutually constructive relationship. If we think of having conversations with our environments in which we each have to learn from each other, then Pask's early experiments with mechanical and electrochemical systems provide a conceptual framework for building interactive artefacts that deal with the natural dynamic complexity that environments must have without becoming prescriptive, restrictive and autocratic. ${ }^{29}$

Indeterminate architecture, one that endlessly adapts to internal and external influences, is of course, well-versed in relation to the Plug-In City ${ }^{30}$ and The Fun Palace ${ }^{31}$. The production 
of the unknown by society is a radical proposition for a discipline where it is the architects who define and create monuments that endure.

This indeterminate vision was soon to become riddled with philosophical and moral complexity with Gordon Pask asking the cybernetics committee what was most likely to induce happiness? A questioned that to all intents and purposes was penned as a beneficial contribution to society. And yet - in the same breath - the neo-futurist aspirations of The Fun Palace, started to border on experiments in social control. ${ }^{32}$ On the flipside, Omar Khan (2009) has commented that society could act back and modify the architectural form to suit their desires. Suggesting 'The Fun Palace has many shortcomings as a design, but there is an incredible optimism in its projections for collective action that still ring true 55 years later, ${ }^{33}$

The conscious city does not escape these binds. ${ }^{34}$ This is a movement of growing momentum in which built environments are aware and responsive to human needs through data analysis, artificial intelligence, and the application of cognitive sciences in design. Such focus on contemporary environments to 'care' invites renewed theoretical consideration, say Philip Beesley and Omar Khan. ${ }^{35}$ In Seeking Empathy in the Conscious City (to be featured in Designing Future Cultures of Care), the ethics of an architectural dialogic in the conscious city are considered - bringing questions of computational neutrality and democratic participation to the fore in the design and curation of 'intelligent architecture'. ${ }^{36}$ Such oppositions hark back to The Fun Palace and Plug-In City, but still find relevance in the architectural discourse of the present.

\section{Conclusion}

This chapter has considered the visionary dreams of two architectural designs Archigram's Plug-In City (1964) designed by Peter Cook and The Fun Palace (1961) conceived by Cedric Price. It took as its focus the key expressions of neo-futurism embodied by these mid-century designs. Through this commentary, it has considered the ways in which time has been conceived of being designed into the fabric of 1960s architecture. And has pulled 
the past through to the present, with particular attention paid to how the tropes of architectural modularism and cybernetics might find relevance in contemporary discourse. Contemporary social theory is suggested as a mechanism to furnish designs of the future with a temporal, situated knowledge, and that there exists value in thinking about the rising number of 'things' sending data across cities as events in time, rather than simply objects in space. Contemplating the recent architectural past in this way, might illuminate and inform, the present and future thought. 


\section{Bibliography}

Beesley, Philip, and Omar. Khan. Responsive Architecture/Performing Instruments. New York: The Architectural League of New York, 2009.

Cook, Peter. Archigram. New York: Princeton Architectural Press, 1999.

Haque, Usman. 'The architectural relevance of Gordon Pask'. AD Architectural Design 77, no. 4 (July-August) (2007): 54-61.

Littlewood, Joan. Joan's Book: Joan Littlewood's Peculiar History as She Tells It. London: Minerva, 1995.

Matthews, Stanley. 'The Fun Palace: Cedric Price's experiment in architecture and technology'. Technoetic Arts: A Journal of Speculative Research 3, no. 2 (2005): 73-91.

Matthews, Stanley. 'The Fun Palace as virtual architecture: Cedric Price and the practices of indeterminacy'. Journal of Architectural Education 59, no. 3 (2006): 39-46.

McAndrew, Claire. and Itati. Palti. (forthcoming). 'Seeking empathy in conscious cities'. In Designing Future Cultures of Care, edited by Laurene Vaughan. London: Bloomsbury, forthcoming 2018.

Sadler, Simon. Archigram: Architecture Without Architecture. London: MIT Press, 2005.

Schatzki, Theodore. The Site of the Social: A Philosophical Account of the Constitution of Social Life and Change. Pennsylvania: Penn State University Press, 2002. 


\section{Captions}

Figure 1. Plug-In City axonometric designed by Peter Cook featured in Archigram Magazine Issue No.4, 1964.

Courtesy The Archigram Archival Project.

Figure 2. Brochure for The Fun Palace Project. Cedric Price (architect) and Joan Littlewood (client), 1964.

Courtesy Canadian Centre for Architecture.

Figure 3. Cover of Archigram Magazine Issue No.7, 1966.

Courtesy The Archigram Archival Project. 
Notes

${ }^{1}$ Peter Cook, Plug-In City Study (London: Archigram Archival Project, 1964), project no.60. Although Plug-In City is commonly attributed to Peter Cook, the study comprised a speculative series of proposals with contributions also made by Warren Chalk and Dennis Crompton.

${ }^{2}$ Cedric Price, Brochure for the Fun Palace Project (Montréal: Canadian Centre for Architecture, 1964), reference no. DR1995:0188:525:001:016.

${ }^{3}$ Despite the prominence of Archigram, work of the collective has been relatively absent in written design history. Molly Wright Steenson's (2017) Architectural Intelligence: How Designers and Architects Created the Digital Landscape (USA, MIT Press) has for instance, looked toward the contributions of Cedric Price, alongside Christopher Alexander, Nicholas Negroponte and Richard Saul Wurman — four architects who engaged with cybernetics and artificial intelligence amongst other technologies during the 1960s and 1970s, as pivotal in the creation of a foundation for today's emergent forms of digital interactivity. Archigram's own historiography has retained an independence from such conversations - see for instance: Simon Sadler's (2005) Archigram: Architecture Without Architecture; Peter Cook's (1999) Archigram supported by Warren Chalk, Dennis Crompton, David Greene, Ron Herron and Mike Webb; A Guide to Archigram (1961-74) written by Dennis Crompton; Yesterday's Future: Visionary Designs by Future Systems and Archigram written by Philipp Sturm and Peter Cachola Schmal (2016) a companion to the exhibition at the Deutsche Architekturmuseum, Frankfurt from 14 May to 18 September 2016; and Beyond Archigram: The Structure of Circulation (2009) by Hadas Steiner. This chapter contributes to today's digital landscape, by considering Archigram's Plug-In City and Cedric Price's Fun Palace through the tropes of architectural modularism, cybernetics, and in the context of contemporary social theory.

${ }^{4}$ Peter Cook, Metal Houses Project (London: Archigram Archival Project, 1961), project no.21. 
${ }^{5}$ Peter Cook, and David Greene, Nottingham Shopping Centre Project (London: Archigram Archival Project, 1962), project no.34.

${ }^{6}$ Living City Exhibition (London: Institute of Contemporary Arts, 1963).

${ }^{7}$ Peter Cook, 'Come-Go: The Key to the Vitality of the City', in Living Arts Magazine (Issue 2 June), ed. Theo Crosby and John Bodley (London: Institute of Contemporary Arts and Tillotsons, 1963), 80.

${ }^{8}$ Simon Sadler, Archigram: Architecture Without Architecture. (London: MIT Press, 2005), 18.

${ }^{9}$ Peter Cook, Plug-In City Study: Sustenance Components Simplified, Guide Section 2 (London: Archigram Archival Project, 1964), project no.60.

${ }^{10}$ Priscilla Chapman, 'The Plug-In City', The Sunday Times Supplement, 20 September 1964, 2.

${ }^{11}$ Chapman, 'The Plug-In City', 3.

${ }^{12}$ Chapman, 'The Plug-In City', 3.

${ }^{13}$ Mike Webb, 'Boys at Heart', in Archigram ed. Peter Cook (supported by Warren Chalk, Dennis Crompton, David Greene, Ron Herron and Mike Webb) (New York: Princeton Architectural Press, 1999), 2.

${ }^{14}$ Price, Brochure for the Fun Palace Project, project no. DR1995:0188:525:001:016.

${ }^{15}$ Stanley Matthews, 'The Fun Palace: Cedric Price's experiment in architecture and technology', Technoetic Arts: A Journal of Speculative Research 3, no. 2 (2005): 79.

${ }^{16}$ Stanley Matthews, 'The Fun Palace as virtual architecture: Cedric Price and the practices of indeterminacy', Journal of Architectural Education 59, no. 3 (2006): 44.

${ }^{17}$ Archigram, 'Zoom and Real Architecture', in Archigram Magazine Issue No.4 (London: Archigram Archival Project, 1964), project no.100.4: 18.

${ }^{18}$ Although this never transpired.

${ }^{19}$ Archigram, 'Zoom and Real Architecture', 18.

${ }^{20}$ Dennis Crompton, Interview with Dennis Crompton (London: Archigram Archival Project, n.d.), project no.100.7. 
${ }^{21}$ Peter Cook, Time Essay, (London: Archigram Archival Project, 1966), project no.100.7: 9. 22 Joan Littlewood, Joan's Book: Joan Littlewood's Peculiar History as She Tells It (London: Minerva, 1995), 702.

${ }^{23}$ Cedric Price, CP3 (London: Archigram Archival Project, 1966), project no.100.7: 13.

${ }^{24}$ Price, CP3, 13.

${ }^{25}$ Matthews, 'The Fun Palace: Cedric Price's experiment in architecture and technology', 91.

${ }^{26}$ Matthews, 'The Fun Palace as virtual architecture: Cedric Price and the practices of indeterminacy', 45-46.

${ }^{27}$ Matthews, 'The Fun Palace as virtual architecture: Cedric Price and the practices of indeterminacy', 42.

${ }^{28}$ Theodore Schatzki, The Site of the Social: A Philosophical Account of the Constitution of Social Life and Change (Pennsylvania: Penn State University Press, 2002), XI.

${ }^{29}$ Usman Haque, 'The architectural relevance of Gordon Pask', AD Architectural Design 77, no. 4 (July-August) (2007): 55.

${ }^{30}$ Simon Sadler, Archigram: Architecture Without Architecture (London: MIT Press, 2005):

16.

${ }^{31}$ Matthews, 'The Fun Palace as virtual architecture: Cedric Price and the practices of indeterminacy', 39-48.

${ }^{32}$ Matthews, 'The Fun Palace: Cedric Price's experiment in architecture and technology', 83.

${ }^{33}$ Philip Beesley, and Omar Khan, Responsive Architecture/Performing Instruments (New York: The Architectural League of New York, 2009), 10.

${ }^{34}$ Itai Palti, and Mosche Bar, 'A Manifesto for Conscious Cities: Should Streets be Sensitive to our Mental Needs?', The Guardian, 28 August 2015.

${ }^{35}$ Beesley and Khan, 'Responsive Architecture/Performing Instruments', 5.

${ }^{36}$ Claire McAndrew, and Itati Palti, 'Seeking Empathy in Conscious Cities'. in Designing Future Cultures of Care, ed. Laurene Vaughan (London: Bloomsbury, forthcoming 2018). 